\title{
Angka Kejadian, Lama Rawat, dan Mortalitas Pasien Acute Kidney Injury di ICU RSUP Dr. Hasan Sadikin Bandung
}

\author{
Hidayat, Nurita Dian Kestriani, Erwin Pradian \\ Departemen Anestesiologi dan Terapi Intensif \\ Fakultas Kedokteran Universitas Padjadjaran/RSUP Dr. Hasan Sadikin Bandung
}

\begin{abstract}
Abstrak
Angka kejadian acute kidney injury (AKI) di ICU tergolong tinggi dengan penyebab utama adalah sepsis dan menjadi salah satu faktor yang memengaruhi lama rawat dan mortalitas pasien di ICU. Angka kejadian, lama rawat, dan mortalitas AKI pada ICU di Indonesia belum diketahui. Tujuan penelitian ini mengetahui angka kejadian AKI, lama rawat dan mortalitas pasien AKI di ICU RSUP dr Hasan Sadikin pada tahun 2018. Penelitian ini merupakan penelitian deskriptif yang dilakukan pada 148 pasien yang dirawat di ICU RSUP dr. Hasan Sadikin Tahun 2018. Diagnosis AKI ditentukan melalui kriteria KDIGO dengan melihat peningkatan kreatinin serum dan penilaian urine output. Penelitian ini dilakukan mulai September 2019 sampai Februari 2020. Pada penelitian ini diperoleh sebanyak 61 pasien $(41,2 \%)$ dengan diagnosis AKI, mayoritas pasien didiagnosis AKI tahap 3 yaitu sebanyak 32 pasien (53\%). Sebanyak 14,8\% pasien mendapatkan renal replacement therapy (RRT. Rerata lama rawat pada pasien AKI di ICU, yaitu 9,4 $\pm 7,2$ hari dan mortalitas sebesar 77\%. Simpulan, angka kejadian AKI di ICU RSUP Dr. Hasan Sadikin Bandung tergolong tinggi, yaitu $41,2 \%$ serta mortalitas yang juga tinggi, yaitu $77 \%$.
\end{abstract}

Kata kunci: Acute kidney injury, angka kejadian, KDIGO, lama rawat, mortalitas

\section{Frequency, Length of Stay, And Mortality of Patients with Acute Kidney Injury at ICU Dr. Hasan Sadikin Hospital Bandung}

\begin{abstract}
Incidence of acute kidney injury (AKI) among patients treated in Intensive Care Units (ICU) is relatively high, mainly due to sepsis. The presence of AKI affects the patient's length of stay (LOS) in the ICU as well as the mortality of ICU patients. In Indonesia, no data is available for the incidence of AKI in ICUs and the LOS and mortality rate of ICU patients with AKI. This study aimed to determine AKI incidence in ICU patients and the length of stay and mortality rate of ICU patients with AKI in Dr. Hasan Sadikin General Hospital in 2018. This was a descriptive study conducted on 148 patients treated at the ICU of Dr. Hasan Sadikin General Hospital 2018. The diagnosis of AKI was confirmed using the Kidney Disease Improving Global Outcomes (KDIGO) criteria by observing the increase in creatinine serum and assessing the urine output. Data were collected during the period of September 2019 to February 2020 for analysis. Results showed that among 61 patients (41.2\%) diagnosed with AKI, the majority were diagnosed with stage 3 AKI ( $n=32 ; 52.5 \%)$. A total of $14.8 \%$ of patients received RRT therapy. The mean LOS of AKI patients in ICU was $9.4 \pm 7.2$ days and the mortality rate was $77 \%$. Thus, the incidence of AKI in the ICU of Dr. Hasan Sadikin General Hospital is relatively high $(41.2 \%)$ with a high mortality rate $(77 \%)$.
\end{abstract}

Key words: Acute kidney injury, frequency, KDIGO, length of stay, mortality

Korespondensi: Hidayat, dr., Departemen Anestesiologi dan Terapi Intensif Fakultas Kedokteran Universitas Padjadjaran/Rumah sakit Umum Pusat Dr. Hasan Sadikin Bandung, Jl. Pasteur No. 38 Bandung 40161, Tlpn 0222038285,Email: hidayat0709@gmail.com 


\section{Pendahuluan}

Acute kidney injury (AKI) merupakan salah satu kondisi yang memengaruhi struktur dan fungsi ginjal. Definisi AKI berdasar atas Kidney Disease Improving Global Outcome (KDIGO) adalah peningkatan kreatinin serum (SCr) $\geq 0,3 \mathrm{mg} / \mathrm{dL}(\geq 26,5 \mu \mathrm{mol} / \mathrm{L})$ dalam 48 jam atau peningkatan kreatinin serum $\geq 1,5$ kali dari nilai awal yang terjadi dalam 7 hari atau volume urin $<0,5 \mathrm{~mL} / \mathrm{kgBB} / \mathrm{jam}$ selama 6 jam. Komplikasi AKI pada pasien kritis akan memengaruhi luaran pasien dalam hal lama rawat, mortalitas, dan biaya perawatan. ${ }^{1}$

AKI sudah dikenal selama beberapa dekade sebagai salah satu kontributor utama yang memengaruhi prognosis pasien dengan penyakit kritis. Penelitian meta-analisis mencakup 154 studi pada lebih dari 3.000.000 individu menyatakan bahwa 1 dari 5 orang dewasa dan 1 dari 3 anak di seluruh dunia mengalami AKI selama perawatan di rumah sakit. ${ }^{2,3}$ Insidensi AKI pada pasien yang dirawat di rumah sakit adalah 7\%, sedangkan insidensi AKI di ruang perawatan intensif (ICU) sekitar 20-50\%. ${ }^{2}$ Derajat AKI itu secara signifikan berkaitan dengan mortalitas pasien. ${ }^{2,4}$

Sampai saat ini belum ada definisi yang seragam untuk AKI dan penelitian tentang angka kejadian AKI pada pasien yang dirawat di rumah sakit terutama pada pasien ICU masih relatif sedikit. Pengaruh AKI terhadap luaran pasien seperti mortalitas dan lama rawat juga juga masih relatif sedikit yang diteliti. ${ }^{5}$ Pada salah satu penelitian ditemukan bahwa $80 \%$ pasien ICU yang mengalami AKI meninggal. Angka mortalitas tersebut tidak berubah meskipun perawatan pasien sudah mengalami perkembangan yang signifikan. Hal ini merupakan konsekuensi dari diagnosis AKI yang sulit dan sering terlambat, usia tua, terdapat komorbid yang lain, serta banyaknya prosedur invasif yang harus dilakukan terhadap pasien. ${ }^{6}$. Dengan mengetahui jumlah kejadian AKI dan pengaruhnya terhadap lama rawat dan mortalitas diharapkan dapat meningkatkan kualitas perawatan terhadap pasien sehingga kejadian AKI dapat berkurang dan luarannya menjadi lebih baik.
Tujuan penelitian ini adalah mengetahui berapa angka kejadian AKI, lama rawat, dan mortalitas pasien AKI di ICU RSUP Dr. Hasan Sadikin tahun 2018.

\section{Subjek dan Metode}

Telah dilakukan satu penelitian observasional retrospektif, berdasarkan data rekam medis selama 1 tahun, yaitu dari 1 Januari sampai 31 Desember 2018, tentang frekuensi, lama rawat, dan mortalitas pasien dengan AKI di Ruang ICU Rumah Sakit Dr. Hasan Sadikin Bandung.

Subjek yang disertakan pada penelitian ini adalah pasien dengan usia sama atau diatas 18 tahun dan dikeluarkan dari subjek penelitian jika mereka mempunyai penyakit ginjal kronik serta data rekam medis yang tidak lengkap.

Variabel yang diukur pada penelitian ini meliputi usia, jenis kelamin, indikasi rawat inap, skor APACHE, AKI berdasar atas kriteria KDIGO (isi tahun publikasi), renal replacement therapy, lama rawat inap (length of stay [LOS]) di ICU, dan mortalitas di ICU.

Penelitian telah mendapatkan persetujuan Komite Etik Penelitian Kesehatan RSUP Dr. Hasan Sadikin Bandung No. LB.02.01/X.6.5/274/2019 dan dilaksanakan bulan September 2019 sampai Februari 2020.

Data hasil penelitian sebagian disajikan dalam bentuk deskriptif dan sebagian setelah dilakukan analisis uji statistik. Uji statistik yang digunakan untuk menganalisis hasil penelitian ini merupakan independent t-test untuk analisis perbedaan nilai variabel dengan nilai numerik dan uji chi-square untuk analisis perbedaan nilai variabel dengan nilai kategorik. Perbedaan disebut bermakna jika ditemukan nilai $p<0,05$. Analisis statistik dikerjakan dengan perangkat lunak statistical product and servise solution (SPPS) versi 24.0 for windows.

\section{Hasil}

Subjek penelitian sebanyak 148 pasien yang disertakan pada penelitian ini usia rerata 48,7 tahun dan 44,3 tahun, rasio laki-laki/ 
Tabel 1 Karakteristik Pasien AKI/Non AKI di ICU RSUP Dr. Hasan Sadikin Bandung Tahun 2018

\begin{tabular}{lcc}
\hline \multicolumn{1}{c}{ Variabel } & AKI & Non AKI \\
\hline Jumlah kejadian, $\mathrm{n}(\%)$ & $61(41 \%)$ & $87(59 \%)$ \\
Derajat AKI (KDIGO), n (\%) & & \\
Tahap 1 & $13(21 \%)$ & \\
Tahap 2 & $16(26 \%)$ & \\
Tahap 3 & $32(53 \%)$ & $44,3 \pm 15,1$ \\
Usia (tahun) & $48,7 \pm 15,9$ & $11,2 \pm 8,0$ \\
Skor APACHE II, \pm SD & $18,6 \pm 10,7$ & \\
Jenis kelamin, n (\%) & & $46(53 \%)$ \\
Laki-laki & $33(54 \%)$ & $41(47 \%)$ \\
Perempuan & $28(46 \%)$ & \\
Indikasi rawat, n (\%) & & $9(10 \%)$ \\
Sepsis & $32(52 \%)$ & \\
Non sepsis & $29(48 \%)$ & \\
Hipovolemia & $20(32,9 \%)$ & \\
Post cardiac arrest & $4(6,5 \%)$ & \\
Trauma & $3(4,9 \%)$ & \\
Eklampsi & $2(3,2 \%)$ & \\
\hline
\end{tabular}

perempuan $54,1 / 45,9$ dan $52,9 / 47,1$ berturutturut pada pasien dengan AKI dan tanpa AKI.

Berdasarkan hasil Uji Shapiro-Wilk, usia pasien baik pada pasien AKI maupun pasien non AKI, terdistribusi normal $(p=0,200)$. Adapun skor acute physiology and chronic health evaluation (APACHE) II pasien pada kedua kelompok pasien tidak terdistribusi normal berdasar atas hasil Uji Shapiro-Wilk $(\mathrm{p}=0,000)$. Dengan demikian, perbedaan usia pasien berdasar atas diagnosis AKI dianalisis dengan uji t-independen, sedangkan perbedaan APACHE skor dengan Uji MannWhitney (Tabel 1).

Rerata usia pada pasien AKI adalah $48,7 \pm 15,9$ tahun, sedangkan pada pasien

Tabel 2 Lama Rawat Pasien AKI di ICU RSUP Dr. Hasan Sadikin Tahun 2018

\begin{tabular}{lccc}
\hline \multirow{2}{*}{ Variabel } & n & \multicolumn{2}{c}{ Lama Rawat (hari) } \\
\cline { 3 - 4 } & & Rerata \pm SD & Median \\
\hline Pasien AKI & 61 & $9,4 \pm 7,2$ & 7,0 \\
Pasien non AKI & 87 & $8,1 \pm 4,6$ & 7,0 \\
Indikasi rawat & & & \\
$\quad$ AKI sepsis & 32 & $6,9 \pm 4,9$ & 5,0 \\
AKI non sepsis & 29 & $12,2 \pm 8,3$ & 10,0 \\
Terapi RRT & & & \\
a. Sepsis & 3 & $7,3 \pm 4,9$ & 5,0 \\
$\quad$ SLEDD & 2 & $10,5 \pm 4,9$ & 10,5 \\
$\quad$ IHD & 27 & $6,5 \pm 5,0$ & 5 \\
$\quad$ Tanpa RRT & & & \\
b. Non sepsis & 2 & $12,5 \pm 3,5$ & 12,5 \\
$\quad$ SLEDD & 2 & $24,5 \pm 7,8$ & 24,5 \\
IHD & 25 & $11,2 \pm 8,1$ & 8,0 \\
$\quad$ Tanpa RRT & & & \\
& & & \\
\hline
\end{tabular}


Tabel 3 Mortalitas Pasien AKI di ICU RSUP Dr. Hasan Sadikin Tahun 2018

\begin{tabular}{lcc}
\multicolumn{1}{c}{ Variabel } & $\begin{array}{c}\text { Hidup } \\
\text { n (\%) }\end{array}$ & $\begin{array}{c}\text { Meninggal } \\
\text { n (\%) }\end{array}$ \\
\hline Pasien AKI & $14(23 \%)$ & $47(77 \%)$ \\
Derajat AKI & 7 & 6 \\
$\quad$ Tahap 1 & 5 & 11 \\
Tahap 2 & 2 & 30 \\
Tahap 3 & & \\
Indikasi rawat & 6 & 26 \\
$\quad$ Sepsis (n=32) & 8 & 21 \\
$\quad$ Non sepsis (n=29) & & \\
Terapi RRT & 0 & 3 \\
Sepsis (n=32) & 0 & 3 \\
IHD & 5 & 21 \\
SLEDD & & \\
Tanpa RRT & 0 & 2 \\
Non sepsis (n=29) & 0 & 2 \\
IHD & 8 & 17 \\
$\quad$ SLEDD & & \\
Tanpa RRT & &
\end{tabular}

non AKI adalah 44,3 $\pm 15,1$ tahun. Hasil uji T-independen menunjukkan tidak terdapat perbedaan usia yang signifikan antara pasien AKI dan pasien non AKI $(\mathrm{p}=0,095)$. Adapun rerata APACHE skor pada pasien AKI adalah $18,6 \pm 10,7$, sedangkan pada pasien non AKI adalah 11,2 $\pm 8,0$. Hasil Uji Mann-Whitney menunjukkan terdapat perbedaan APACHE score yang signifikan antara pasien AKI dan pasien non AKI $(\mathrm{p}=0,000)$.

Mayoritas pasien AKI berjenis kelamin laki-laki (33 dari 148 pasien), demikian juga pada pasien non AKI (46 dari 148 pasien). Berdasarkan hasil uji chi-square tidak terdapat perbedaan jenis kelamin yang signifikan antara pasien AKI dan pasien non AKI ( $p=1,000)$.

Mayoritas pasien AKI merupakan pasien dengan sepsis (32 dari 148 pasien), sedangkan mayoritas pasien non AKI merupakan pasien non sepsis (78 dari 148 pasien). Berdasarkan hasil uji chi-square (koreksi kontinuitas), terdapat perbedaan yang signifikan antara pasien AKI dan pasien non AKI $(\mathrm{p}=0,000)$. Tampak bahwa pasien AKI lebih didominasi pasien sepsis, sedangkan pasien non AKI lebih didominasi pasien non sepsis. Hasil analisis juga menunjukkan bahwa dari total 41 pasien sepsis, mayoritas pasien didiagnosis AKI (32 dari 148 pasien), sedangkan dari total 107 pasien non sepsis, mayoritas pasien didiagnosis non AKI (78 pasien).

Lama rawat rerata pasien AKI adalah $9,4 \pm 7,2$ hari. Lama rawat rerata pasien AKI dengan sepsis adalah $6,9 \pm 4,9$ hari, sedangkan pasien AKI non sepsis adalah $12,2 \pm 8,3$ hari (Tabel 2).

Berdasar atas hasil Uji Saphiro-Wilk didapatkan lama rawat pasien AKI dan non AKI tidak berdistribusi normal $(p=0,000)$ sehingga data dianalisis dengan Uji MannWhitney. Dari hasil analisis denganUji MannWhitney tidak terdapat perbedaan lama rawat yang signifikan antara pasien AKI dan Non AKI, dari uji Saphiro-Wilk didapatkan lama rawat AKI sepsis tidak berdistribusi normal $(p=0,001)$ dan lama rawat AKI non sepsis berdistribusi normal $(p=0,007)$. Oleh karena itu, perbandingan lama rawat antara pasien AKI sepsis dengan AKI non sepsis juga dianalisis dengan Uji Mann-Whitney. Dari hasil analisis didapatkan perbedaan yang signifikan antara lama rawat pasien AKI sepsis dengan AKI non sepsis.

Dari total 61 pasien AKI sebanyak 47 dari 61 pasien meninggal. Sebagian besar pasien AKI yang meninggal ditemukan pada kasus AKI derajat 3 (64\%) dan sepsis (55\%). Baik pada kelompok AKI disertai sepsis maupun AKI tanpa disertai sepsis, kematian paling banyak ditemukan pada kelompok AKI tanpa 
terapi RRT yaitu 77\% (kelompok sepsis) dan 81\% (kelompok non sepsis; Tabel 3).

Dari hasil analisis menggunakan uji chisquare didapatkan hubungan yang signifikan antara kejadian AKI dengan mortalitas pasien $(p=0,000)$. Analisis statistik pada AKI sepsis dan non sepsis terhadap mortalitas dengan uji chi-square didapatkan hasil bahwa kejadian sepsis tidak signifikan memengaruhi mortalitas pada pasien AKI $(\mathrm{p}=0,412)$.

\section{Pembahasan}

Hasil penelitian menunjukkan bahwa angka kejadian acute kidney injury (AKI) di ICU RSUP Dr Hasan Sadikin Bandung tahun 2018 tergolong tinggi yaitu sebesar $41,2 \%$. Pasien AKI didominasi AKI tahap 3 (53\%), selanjutnya tahap 2 (26\%) dan tahap 1 (21\%). Hasil ini sesuai dengan salah satu penelitian yang pernah dilakukan ditemukan angka kejadian AKI di ICU sebesar 50,1\% dengan AKI tahap 3 lebih banyak, yaitu 44,8\%. Beberapa publikasi tentang epidemiologi AKI melaporkan angka kejadian yang sangat bervariasi mulai dari $26 \%$ hingga $67 \%$. Angka kejadian yang dilaporkan bergantung pada populasi yang diteliti dan pada kriteria diagnostik yang digunakan (RIFLE/AKIN/KDIGO). ${ }^{7}$ Salah satu penelitian lain yang menggunakan kriteria KDIGO menunjukkan bahwa 1 dari 5 orang dewasa dan 1 dari 3 anak mengalami AKI di seluruh dunia. Angka kejadian AKI yang paling tinggi ditemukan pada pasien yang dirawat di ICU dan pasien postoperasi jantung yang menjadikannya sebagai populasi berisiko tinggi dan sangat membutuhkan intervensi. ${ }^{3}$

Penyebab angka kejadian AKI yang tinggi di ICU sebagian besar disebabkan oleh pasien kritis sudah mengalami kegagalan organ multisistem. Ginjal adalah organ yang sangat rentan. Kerusakan parenkim ginjal dapat diawali dengan hipoperfusi yang akhirnya menyebabkan kerusakan tubulus ginjal atau kerusakan langsung pada jaringan interstitial ginjal. Karakteristik pasien di ICU yang berhubungan dengan terjadi komplikasi AKI antara lain usia tua, diabetes, gagal jantung, sepsis, penggunaan obat-obat nefrotoksik, penggunaan vasopresor atau inotropik, pasien yang menjalani pembedahan risiko tinggi, pembedahan emergency, dan hipertensi. ${ }^{8}$ Pada penelitian ini tidak dideskripsikan mengenai onset dan faktor risiko AKI karena keterbatasan data dan kesulitan mendiagnosis AKI yang tepat. Beberapa penelitian juga menyatakan bahwa keterbatasan sumber daya kesehatan yang tersedia di beberapa negara juga menyebabkan angka kejadian AKI tinggi karena identifikasi pasien yang berisiko tinggi terhadap AKI dan diagnosis dini AKI sangat penting dalam menurunkan kejadian AKI dan meningkatkan keberhasilan pemulihan fungsi ginjal. ${ }^{9}$ Idealnya fungsi ginjal harus dipantau secara berkala supaya AKI dapat diketahui secepatnya dan mendapatkan tatalaksana yang tepat. Diagnosis AKI yang didasarkan atas kenaikan kreatinin serum dan urine output memiliki keterbatasan karena marker ini tidak spesifik untuk ginjal. ${ }^{10}$ Kesulitan dalam diagnosis AKI dan keterlambatan diagnosis menyebabkan AKI berkembang menjadi lebih berat sehingga pada penelitian ini pasien AKI tahap 3 paling banyak ditemukan.

Beberapa biomarker telah diketahui dapat digunakan untuk mengetahui kerusakan ginjal lebih awal daripada kreatinin, akan tetapi beberapa biomarker ini belum sering digunakan. Biomarker ini dibagi menjadi dua yaitu biomarker yang merefleksikan fungsi ginjal (kreatinin serum, urine output, dan cystatin ( serum) dan biomarker yang merefleksikan cedera pada ginjal (neutrophil gelatinase-associated lipocalin (NGAL); kidney injury molecule-1 (KIM-1); tissue inhibitor of metalloproteinases 2 (TIMP2); insulin-like growth factor-binding protein 3 (IGFBP3), dan lain-lain). ${ }^{11}$

Cystatin $\mathrm{C}$ adalah suatu protein berukuran kecil yang diproduksi oleh sel berinti yang eliminasinya bergantung pada GFR. Cystatin C mirip dengan kreatinin, tetapi tidak dapat diproduksi oleh sel otot. Cystatin C dapat mendeteksi AKI 1-2 hari lebih cepat sebelum terjadi peningkatan kreatinin. Biaya pemeriksaan yang mahal menyebabkan cystatin C ini jarang digunakan. Molekul seperti NGAL dan KIM-1 juga dapat memprediksikan 
kerusakan ginjal lebih awal sebelum terjadi peningkatan kreatinin. Penggunaan rutin NGAL terbatas karena peningkatan NGAL dalam darah dan urin dapat dipengaruhi oleh kondisi inflamasi sistemik termasuk sepsis yang belum tentu mengalami AKI. Biomarker AKI lainnya masih dievaluasi dan diteliti untuk penggunaan secara rutin pada praktik klinis. ${ }^{11}$

Rerata usia pasien AKI adalah 48,7 $\pm 15,9$ tahun, tidak berbeda secara signifikan dengan pasien non AKI. Pada salah satu penelitian multicenter yang dilakukan di Australia didapatkan bahwa rerata usia pasien AKI adalah 50,8-75,4 tahun. ${ }^{12}$ Pada penelitian lain didapatkan bahwa pasien yang mengalami AKI di ICU rerata usia 53-78 tahun. ${ }^{13}$ Pola pasien AKI berbeda di seluruh dunia. Di negara maju kebanyakan pasien AKI berusia tua dan memiliki penyakit kronik seperti keganasan, diabetes melitus, dan penyakit kardiovaskular. AKI yang terjadi pada usia tua sebagian besar disebabkan oleh iskemia dan/ atau obat nefrotoksik dan sering berkaitan dengan kegagalan organ yang lain. Di negara berkembang AKI cukup banyak terjadi pada pasien yang berusia lebih muda dengan penyebab yang lebih kompleks seperti penyakit infeksi, toksin, penggunaan obatobat tradisional, komplikasi kehamilan, serta penyebab lainnya. ${ }^{14}$ Harapan hidup pasien AKI menurun sesuai dengan pertambahan usia. Pada salah satu penelitian ditemukan bahwa mortalitas pasien yang berusia $>50$ tahun memiliki risiko dua kali lebih besar. ${ }^{15}$

Skor rerata APACHE II pada pasien AKI adalah 18,6 $\pm 10,7$; lebih tinggi dibanding dengan pasien non AKI $(11,2 \pm 8,0)$. Rerata skor APACHE II pada penelitian ini tidak terlalu berbeda dengan penelitian yang dilakukan di China didapatkan rerata skor APACHE II pada pasien AKI, yaitu 17 (12-23). ${ }^{13}$ Skor APACHE II merupakan salah satu sistem skoring yang telah digunakan secara luas untuk memperkirakan prognosis dan mortalitas pasien yang dirawat di ICU. Sistem skor APACHE II ini memiliki keuntungan karena mudah digunakan dan sudah sering digunakan untuk stratifikasi risiko pada AKI dibanding dengan sistem skoring yang lain. ${ }^{16}$ Skor APACHE II ini dinilai saat 24 jam pertama pasien masuk ke ICU. Jumlah skor paling tinggi APACHE II ini adalah 71, skor 25 menunjukkan kemungkinan mortalitas sebesar 50\%, sedangkan skor di atas 35 menunjukkan kemungkinan mortalitas 80\%. ${ }^{17}$ Pada salah satu penelitian dinyatakan bahwa skor APACHE II yang tinggi merupakan salah satu faktor risiko AKI pada pasien yang dirawat di ICU. Skor APACHE II yang tinggi juga menggambarkan beratnya penyakit pasien dan berkaitan dengan peningkatan kebutuhan terhadap ventilasi mekanik, vasopresor, dan kegagalan organ lain. ${ }^{18}$

Pasien AKI didominasi oleh pasien sepsis sebanyak 53\%, sebaliknya pasien non AKI didominasi oleh pasien nonsepsis sebanyak 90\%. Temuan ini sesuai dengan hasil penelitian sebelumnya bahwa sepsis itu merupakan penyebab utama AKI. ${ }^{19}$ Demikian pula bahwa sepsis merupakan penyebab terbanyak kasus AKI di ICU (45-70\%). ${ }^{1}$ Mekanisme bagaimana sepsis dapat menyebabkan AKI belum sepenuhnya dipahami. Disfungsi organ pada sepsis terjadi melalui beberapa mekanisme, yaitu inflamasi, gangguan mikrosirkulasi, dan perubahan metabolik. Pada kondisi sepsis, mediator inflamasi termasuk molekul yang bersifat patogen dan merusak dilepaskan ke dalam pembuluh darah. Molekul tersebut akan berikatan dengan reseptor seperti Toll Like Receptor (TLR) yang berada di permukaan sel imun dan akan mengaktivasi kaskade yang menghasilkan pelepasan molekul proinflamasi. Pada sel epitel tubulus ginjal juga terdapat toll like receptor terutama TLR 2 dan TLR 4, jika berikatan dengan molekul inflamasi yang bersifat patogen akan terjadi kerusakan glomerulus dan area peritubuler. Pada saat terjadi kerusakan, sel epitel tubular ginjal akan memulai paracrine signaling yang akan memberikan sinyal kepada sel yang berada di sekitarnya untuk deaktivasi dan mengorbankan fungsinya dalam rangka meminimalkan kematian sel. ${ }^{20}$

Perfusi jaringan memiliki peran penting dalam mempertahankan fungsi organ yang adekuat. Perubahan pada keseimbangan penghantaran oksigen dan konsumsi oksigen selalu menjadi penyebab kerusakan organ 
pada sepsis. Gangguan perfusi jaringan ini tidak selalu berkaitan dengan kelainan sirkulasi sitemik. Pada beberapa penelitian yang pernah dilakukan diketahui bahwa perubahan mikrosirkulasi terjadi pada saat sepsis meskipun tidak ditemukan gangguan pada makrosirkulasi. Berbagai mekanisme dapat menyebabkan perubahan mikrosirkulasi seperti kerusakan endotel, respons sistem saraf autonom, kerusakan glycocalyx, dan aktivasi kaskade koagulasi. Kerusakan endotel berkaitan dengan vasodilatasi, peningkatan permeabilitas pembuluh darah, dan kebocoran endotel. Laju filtrasi glomerulus ditentukan oleh tekanan hidrostatik intraglomerulus, konstriksi arteriole afferent ginjal, dan dilatasi arteriole efferent diketahui sebagai mekanisme yang menurunkan tekanan hidrostatik intraglomerulus sehingga laju fitrasi glomerulus berkurang. ${ }^{20}$

Pada keadaan sepsis juga terjadi perubahan metabolisme untuk mengurangi jumlah kematian sel epitel tubulus ginjal. Beberapa teori telah dikemukakan untuk dapat mengetahui perubahan metabolisme yang terjadi pada sel epitel tubulus ginjal selama kondisi sepsis. Sebagian besar teori mengarah ke proses perubahan metabolisme pada mitokondria sel. Proses ini ditandai dengan optimalisasi pengeluaran energi, pengaturan ulang penggunaan substrat, dan pencegahan apoptosis. Inflamasi berkaitan dengan optimalisasi penggunaan energi ditandai dengan pengurangan penggunaan energi pada fungsi sel yang nonvital (seperti sintesis protein atau transpor ion) dan mempertahankan penggunaan energi untuk fungsi sel yang vital (seperti fungsi membran ATP $\mathrm{Na}^{+} / \mathrm{K}^{+}$) untuk mencegah kematian sel sehingga terjadi penurunaan fungsi transpor ion dan cairan oleh tubulus ginjal. ${ }^{20}$

Pada AKI dengan sepsis akibat bakteri gram negatif ditemukan peningkatan konsentrasi endotoksin plasma (lipopolisakarida;LPS) pada sirkulasi sistemik. LPS ini berasal dari translokasi flora normal bakteri gram negatif di usus dan perkembangbiakan serta penghancuran bakteri gram negatif yang menghasilkan pelepasan LPS ke dalam aliran darah dan secara cepat menyebar ke seluruh tubuh. LPS ini akan berikatan dengan LPS binding protein (LBP). Gabungan LPS-LBP ini berikatan dengan co-receptor CD 14 lalu berinteraksi dengan permukaan sel tol like receptor 4-MD-2 pada makrofag, monosit, neutrofil, serta sel epitel tubulus ginjal. ${ }^{21}$ Interaksi tersebut akan mengeluarkan sitokin proinflamasi seperti tumor necrosis factor (TNF), interleukin (IL)-1, interferon (IFN). Pada ginjal terbentuk reseptor 1 TNF pada sel endotel glomerulus dan reseptor $2 \mathrm{TNF}$ pada sel epitel tubulus. Setelah serangkaian reaksi terjadi transkripsi gen inducible NO Synthase (iNOS) dan translasi iNOS mRNA yang menghasilkan pembentukan nitric oxide (NO). Pembentukan sejumlah besar NO selama sepsis bertanggung jawab atas vasodilatasi sistemik yang menyebabkan syok septik. Deplesi volume arteri menyebabkan stimulasi baroreseptor yang memicu peningkatan aktivitas simpatis dan produksi angiotensin. Hal tersebut menyebabkan vasokonstriksi intrarenal dengan retensi natrium dan air serta pengurangan laju filtrasi glomerulus (GFR). Pada percobaan terhadap hewan telah terbukti bahwa LPS dapat menyebabkan gagal ginjal tanpa disertai hipotensi yang signifikan. $^{21}$

Penyebab AKI yang berikutnya, yaitu hipovolemia yang disebabkan oleh beberapa kondisi seperti perdarahan, muntah, diare, asupan diet yang buruk, luka bakar, dan lain sebagainya. Hipovolemia akan mengganggu perfusi ginjal sehingga dapat terjadi gangguan fungsi ginjal. ${ }^{22}$ Hal ini sesuai dengan salah satu penelitian bahwa sepsis menjadi faktor presipitasi utama terjadi AKI (47\%) diikuti oleh hipovolemia (32\%). ${ }^{23}$ Hasil penelitian juga menunjukkan bahwa dari total 41 pasien sepsis, mayoritas pasien didiagnosis AKI (32 pasien atau $78 \%$ pasien), sedangkan dari total 107 pasien nonsepsis, mayoritas pasien tidak mengalami AKI (78 pasien atau 73\% pasien). Hal ini menunjukkan bahwa pasien sepsis memiliki risiko yang lebih besar mengalami AKI dibanding dengan pasien nonsepsis.

Rerata lama rawat pasien AKI adalah $9,4 \pm 7,2$ hari, lebih lama dibanding dengan 
pasien yang tidak memiliki AKI. Rerata lama rawat pasien AKI dengan indikasi rawat sepsis $(6,9 \pm 4,9$ hari) relatif lebih rendah daripada pasien AKI dengan indikasi rawat nonsepsis $(12,2 \pm 8,3$ hari). AKI dengan sepsis memiliki prognosis yang lebih buruk dan mortalitas yang lebih tinggi dibanding dengan AKI tanpa sepsis. ${ }^{24}$ Pada penelitian ini pasien AKI dengan sepsis memiliki lama rawat yang lebih pendek karena sebagian besar pasien mengalami mortalitas yang lebih cepat dibanding dengan pasien AKI tanpa sepsis. Pasien AKI yang membutuhkan dialisis akan memiliki lama rawat yang lebih lama dibanding dengan pasien yang tidak membutuhkan dialisis. ${ }^{18} \mathrm{Hal}$ ini disebabkan oleh pasien yang dilakukan RRT merupakan pasien AKI berat yang memiliki gejala kelebihan cairan, hiperkalemia, asidosis, dan tanda-tanda uremikum. Pasien AKI yang mendapatkan terapi IHD secara klinis memiliki lama rawat yang lebih lama, yaitu $17,5 \pm 9,6$ hari dibanding dengan terapi SLEDD 9,4 $\pm 4,8$ hari. SLEDD diindikasikan untuk pasien AKI dengan hemodinamik yang tidak stabil sehingga pasien SLED memiliki risiko mortalitas yang lebih tinggi dibanding dengan pasien yang diberikan IHD. Pada penelitian ini pasien yang diberikan SLEDD memiliki lama rawat yang lebih pendek karena lebih dulu mengalami mortalitas dibanding dengan pasien IHD. Banyak faktor yang dapat memengaruhi lama rawat pasien AKI. Hipotensi, penggunaan ventilasi mekanik invasif, skor APACHE II dan GCS, derajat AKI, nilai kreatinin dan ureum serum tertinggi, penggunaan hemodialisis, dan leukositosis dapat memengaruhi secara signifikan pemanjangan lama rawat pasien AKI. Usia, jenis kelamin, ada komorbid (diabetes melitus, hipertensi, penyakit jantung iskemik), merokok, alkohol, urine output, asidosis metabolik, hemoglobin, nilai kreatinin dan ureum serum pada saat pertama terdiagnosis AKI diketahui tidak berpengaruh secara signifikan terhadap lama rawat pasien $\mathrm{AKI}^{25}$

Beberapa modalitas RRT sudah digunakan dalam penatalaksanaan $\mathrm{AKI}^{26}$ Salah satu penelitian multicenter menyatakan bahwa modalitas RRT yang sering digunakan untuk penatalaksanaan AKI adalah CRRT (80\%), IHD (16,9\%), dan SLEDD (3,2\%). ${ }^{27}$ Pada penelitian ini, mayoritas pasien AKI tidak mendapatkan terapi RRT (52 dari 61 pasien) dan sisanya mendapatkan terapi IHD atau SLEDD ( 9 dari 61 pasien). Tidak ada pasien yang mendapatkan terapi CRRT. Dari 32 pasien AKI tahap 3 sesuai kriteria KDIGO, hanya 9 pasien yang mendapatkan terapi RRT sedangkan 23 pasien tidak mendapatkan terapi RRT. Hal ini tidak dapat diketahui secara pasti penyebabnya karena keterbatasan data dan penelitian yang dilakukan secara retrospektif.

Pasien memperoleh terapi IHD dan SLEDD dengan frekuensi terapi yang berbeda-beda yaitu 2 pasien mendapatkan terapi IHD sebanyak 1 kali selama dirawat 7 hari dan 30 hari di ICU, 1 pasien mendapatkan terapi IHD sebanyak 2 kali selama dirawat 14 hari di ICU, 1 pasien diberikan terapi IHD sebanyak 5 kali selama dirawat 19 hari di ICU. 3 pasien mendapatkan terapi SLEDD 1 kali selama perawatan masing-masing 4 hari, 5 hari, dan 15 hari di ICU. Dua pasien mendapatkan terapi SLEDD sebanyak $4 \mathrm{x}$ selama dirawat 10 hari dan 13 hari di ICU. Pada penelitian ini tidak dapat diketahui secara pasti tentang pertimbangan pemberian RRT karena penelitian yang dilakukan secara retrospektif dan keterbatasan data.

Sampai saat ini masih belum terdapat kesepakatan tentang kapan mulai diberikan RRT. Pemberian RRT masih berdasar atas kelebihan cairan, azotemia, hiperkalemia, dan asidosis metabolik berat. Bila tidak ditemukan keadaan tersebut pada umumnya dialisis dihindari karena masih ada kemungkinan kondisi pasien dapat pulih sendiri dan risikorisiko yang berkaitan dengan pemberian RRT seperti hipotensi, aritmia, komplikasi dari akses vaskular dan pemberian antikoagulan. ${ }^{1}$

Faktor lain yang dapat memengaruhi keputusan untuk memulai pemberian RRT antara lain berat penyakit dasar pasien yang dapat memengaruhi pulihnya fungsi ginjal, disfungsi organ lain yang menurunkan toleransi tubuh terhadap kelebihan cairan, tumor lysis syndrome, dan kebutuhan untuk pemberian cairan misalnya untuk nutrisi dan 
obat. KDIGO memberikan 2 rekomendasi tentang waktu pemberian RRT; yang pertama pemberian RRT dapat segera dilakukan jika didapatkan perubahan keseimbangan cairan, elektrolit, dan asam basa yang mengancam jiwa. Rekomendasi KDIGO yang kedua, yaitu pemberian RRT dapat dilakukan dengan melihat cakupan klinis yang lebih luas dengan mempertimbangkan kondisi yang dapat diperbaiki dengan pemberian RRT tersebut. Keputusan menghentikan RRT harus betul-betul dipertimbangkan dengan memperhatikan pulihnya fungsi ginjal dan perbaikan kondisi yang dapat mengganggu fungsi ginjal. ${ }^{1}$

Masih banyak hal diperdebatkan tentang pemberian terapi RRT yang optimal meliputi waktu pemberian, modalitas terapi, dosis, jenis antikoagulan, dan tata laksana cairan. Pada salah satu penelitian diketahui bahwa prognosis pasien AKI yang membutuhkan RRT lebih buruk dibanding dengan pasien yang mendapatkan terapi konservatif dikarenakan pasien yang mendapatkan RRT memiliki risiko mortalitas yang secara signifikan lebih tinggi dibanding dengan yang tidak mendapatkan RRT. Hal ini disebabkan karena RRT biasanya diberikan pada pasien AKI berat dengan komplikasi yang mengancam nyawa dan juga karena berbagai efek samping pemberian RRT yang merugikan. ${ }^{28}$ Pada penelitian ini tidak dapat diketahui secara pasti tentang pertimbangan pemberian RRT terhadap pasien karena keterbatasan data dan penelitian yang dilakukan retrospektif.

Pada penelitian ini mortalitas pasien AKI adalah $77 \%$. pasien yang mengalami mortalitas paling banyak, yaitu AKI tahap 3 sebanyak 30 dari 47 pasien. Pasien dengan sepsis juga mengalami mortalitas yang lebih tinggi dibanding dengan pasien yang tidak sepsis. Pada penelitian retrospektif yang pernah dilakukan sebelumnya didapatkan mortalitas pasien AKI di ICU sebesar 52\%. Faktor risiko yang berkaitan dengan mortalitas pada pasien AKI di ICU meliputi usia tua, lama rawat yang koma, skor APACHE II yang tinggi, terdapat komorbid, oliguria, hipovolemia, asidosis metabolik, sepsis, trauma multipel, penggunaan ventilasi mekanik dan obat vasopresor. ${ }^{6}$

Keterbatasan penelitian ini adalah sebagian besar pasien tidak memiliki nilai kreatinin basal sehingga diagnosis AKI berdasar atas peningkatan nilai kreatinin dari nilai kreatinin awal saat masuk ICU serta melihat perubahan urine output sesuai dengan kriteria KDIGO. Selain itu, pada penelitian ini tidak semua pasien memiliki skor APACHE II.

\section{Simpulan}

Angka kejadian acute kidney injury di ICU RSUP Hasan Sadikin pada tahun 2018 yaitu $41,2 \%$ dengan paling banyak derajat AKI tahap 3. Length of stay pasien AKI di ICU RSUP Dr. Hasan Sadikin tahun 2018, yaitu 9,4 $\pm 7,2$ hari. Angka mortalitas AKI di ICU RSUP Dr. Hasan Sadikin pada tahun 2018 cukup tinggi.

\section{Daftar Pustaka}

1. Kellum J, Lameire N, Aspelin P, Barsoum R, Burdmann E, Goldstein S, dkk. Clinical practice guideline for acute kidney injury. KDIGO. 2012;2(1):1-141.

2. Doi K. Role of kidney injury in sepsis. J intensive Care Med. 2016;4:17.

3. Susantitaphong P, Cruz DN, Cerda J, Abulfaraj M, Alqahtani F, Kouloridis I, dkk. World incidence of AKI: a meta analysis. Clin J Am Soc Nephrol. 2013;8:1482-93.

4. Srisawat N, Hoste E, Kellum JA. Modern classification of acute kidney injury. Blood Purif. 2010;29:300-7.

5. Chertow GM, Burdick E, Honour M, Bonventre JV, Bates DW. Acute kidney injury, mortality,length of stay, and cost in hospitalized patients. J Am Soc Nephrol. 2005;16:3365-70.

6. Perez LA, Wandeur V, Matsuo T. Predictors of acute kidney injury and mortality in an intensive care unit. J Bras Nefrol. 2015;37(1):38-46.

7. Tejera D, Varela F, Acosta D, Figueroa S, BenencioS, Verdaguer C, dkk. Epidemiology of acute kidney injury and chronic kidney disease in the intensive care unit. Rev Bras 
Ter Intensiva. 2017;29(4):444-52.

8. Cartin-Ceba R, Kashiouris M, Plataki M, Kor DJ, Gajic O, Casey ET. Risk factors for development of acute kidney injury in criticallyillpatients:asystematicreviewand meta-analysis of observational studies. Crit Care Res Pract. 2012;2012:691013. doi:10.1155/2012/691013.

9. Dos Santos RP, Carvalho AR, Peres LA. Incidence and risk factors of acute kidney injury in critically ill patients from a single centre in Brazil: a retrospective cohort analysis. Sci Rep. 2019;9:18141.

10. Pickkers $P$, Ostermann $M$, Joannidis M, Zarbock A, Hoste E, Bellomo R, dkk. The intensive care medicine agenda on acute kidney injury. Intens Care Med. 2017;43(9):1198-209.

11. Mohsenin V. Practical approach to detection and management of acute kidney injury in critically ill patient. $J$ Intensive Care. 2017;5:57.

12. Bagshaw SM, George G, Dinu I, Bellomo R. A multi-centre evaluation of the RIFLE criteria for early acute kidney injury in critically ill patients. Nephrol Dial Transplant. 2008;23:1203-10.

13. Xuying L, Li J, Bin D, Ying W. A comparison of different diagnostic criteria of acute kidney injury in critically ill patient. Crit Care. 2014;18:R144.

14. Elhafeez SA, Tripepi G, Quinn R, Naga Y, Abdelmonem S, Abdelhady M, dkk. Risk, predictors, and outcomes of acute kidney injury in patients admitted to intensive care units in Egypt Sci Rep. 2017;7(1):17163

15. Lopes J, Jorge S. The RIFLE and AKIN classifications for acute kidney injury: a critical and comprehensive. Clin Kidney J. 2013;6:8-14.

16. Yung-chang $\mathrm{C}$, Hsiang-hao $\mathrm{H}$, Kuo-chin $\mathrm{K}$, Ji-tseng $\mathrm{F}$, Chiu-ching $\mathrm{H}$. Outcomes and APACHE II predictions for critically ill patients with acute renal failure requiring dialysis. Renal Failure. 2001;23(1):61-70.

17. Bouch DC, Thompson JP. Severity scoring system in the critically ill. Brit J Anaesthesia. 2008;8:181-5.

18. Yong M, Zonghe Q. Risk factors of acute kidney injury and dialysis among patients attending intensive care units in China. Int J Clin Exp Med. 2017;10(8):12056-67.

19. Bellomo R, Ronco C, Kellum JA, Mehta RL, Palevsky P, the ADQI workgroup. Acute renal failure-definition, outcome measures, animal models, fluid therapy and information technology needs: the second international consensus conference of the Acute Dialysis Quality Initiative (ADQI) group. Crit Care. 2004;8:R204-12.

20. Peerapornratana S, Cabalero C, Gomez $\mathrm{H}$, Kellum JA. Acute kidney injury from sepsis: current concepts, epidemiology, pathophysiology, prevention, and treatment. Kidney Int. 2019;96(5):108399.

21. Majumdar A. Sepsis-induced acute kidney injury. Indian J Crit Care Med. 2010;14(1):14-21.

22. Basile D, Anderson M, Sutton T. Pathophysiology of acute kidney injury. Compr Physiol. 2012;2(2):1303-53.

23. Ali T, Khan I, Simpson W, Prescott G, Townend J, Smith W, dkk. Incidence and outcomes in acute kidney injury: a comprehensive population-based study. J Am Soc Nephrol. 2007;18:1292-8.

24. Bagshaw SM, Uchino S, Bellomo R, Morimatsu H, Morgera S, Schetz M, dkk. Septic acute kidney injury in critically ill patients: clinical characteristics and outcomes. Clin J Am Soc Nephrol. 2007;2(3):431-9.

25. Saxena A, Prasad RN, Meshram SV. Factors predicting length of hospital stay in acute kidney injury patients admitted in a rural tertiary care hospital. Acta Scie Med Sci. 2017;1(2):19-23.

26. Bellomo R, Ronco C, Mehta R, Asfar P, Boisramé-Helms J, Darmon M, dkk. Acute kidney injury in the ICU: from injury to recovery: reports from the 5th Paris International Conference. Ann Intensive Care. 2017;7:49.

27. Uchino S, Kellum JA, Bellomo R, Doig GS, Morimatsu H, Morgera S, dkk. Acute renal failure in critically ill patients, a multinational multicenter study. JAMA. 
118 | p-ISSN 2337-7909; e-ISSN 2338-8463; http://

2005;294:813-8.

28. Elseviers MM, Lins RL, Niepen PV, Hoste E, Malbrain ML, Damas P, dkk.Renal replacement therapy is an independent risk factor for mortality in critically ill patients with acute kidney injury. Crit Care. 2010;14:R221. 